\title{
Health-Promoting Capacities of In Vitro and Cultivated Goji (Lycium chinense Mill.) Fruit and Leaves; Polyphenols, Antimicrobial Activity, Macro- and Microelements and Heavy Metals
}

\author{
Arleta Kruczek ${ }^{1}$, Marcelina Krupa-Małkiewicz ${ }^{2}$ D, Sabina Lachowicz ${ }^{3}{ }^{(D)}$, Jan Oszmiański ${ }^{4}$ and $^{-}$ \\ Ireneusz Ochmian 1,*(D) \\ 1 Department of Horticulture, West Pomeranian University of Technology Szczecin, Słowackiego 17 Street, \\ 71-434 Szczecin, Poland; ka21499@zut.edu.pl \\ 2 Department of Plant Genetics, Breeding and Biotechnology, West Pomeranian University of Technology \\ Szczecin, Słowackiego 17 Street, 71-434 Szczecin, Poland; Marcelina.Krupa-Malkiewicz@zut.edu.pl \\ 3 Department of Fermentation and Cereals Technology, Wrocław University of Environmental and Life \\ Science, 37, Chełmońskiego Street, 51-630 Wroclaw, Poland; sabina.lachowicz@upwr.edu.pl \\ 4 Department of Fruit, Vegetable and Plant Nutraceutical Technology, Wrocław University of Environmental \\ and Life Science, 37, Chełmońskiego Street, 51-630 Wroclaw, Poland; jan.oszmianski@upwr.edu.pl \\ * Correspondence: iochmian@zut.edu.pl; Tel.: 0048-91-449-6163 \\ Academic Editor: Francesco Cacciola \\ Received: 26 October 2020; Accepted: 12 November 2020; Published: 14 November 2020

\begin{abstract}
There is a growing interest among the public in fruit with a positive impact on human health. Two goji berry cultivars ('No. 1' and 'New Big') were propagated in vitro, grown in an orchard and then evaluated for macro- and microelements and harmful heavy metals (i.e., $\mathrm{Pb}, \mathrm{Ni}$, and $\mathrm{Cd}$ ). The leaves and fruit were also assessed for nutritional value, polyphenols and the antimicrobial activity of the leaves. 'New Big' was characterized by a higher content of macro elements in the leaves (in vitro and orchard) and a higher content of microelements in the fruit. The harmful substances content was below the minimum value. Furthermore, neither the fruit nor the leaves contained cadmium. This study also indicated that leaves had a higher content of polyphenols compared to the fruit. The fruits were characterized by their health-promoting capacities, while the leaves were characterized by their antibacterial activity. Among the Gram-positive bacteria, the most sensitive strain was Bacillus subtilis, and among the Gram-negative bacteria, it was Proteus vulgaris. Taking into consideration the Recommended Daily Allowance (RDA) for minerals, goji berries can be declared to be a source of $\mathrm{Cu}, \mathrm{Fe}, \mathrm{Mn}, \mathrm{Zn}$ and $\mathrm{P}$.
\end{abstract}

Keywords: antioxidant; antibacterial activity; mineral elements; in vitro; fruit; leaves

\section{Introduction}

The consumption of red berries has increased considerably in recent years. Werewolf berries (Lycium chinense Mill, Solanaceae), traditional food and medicines in East Asia, have become progressively more popular in Europe and North America [1-3] since the beginning of the 21st century. Two closely related species, L. barbarum and L. chinenese, are well known around the world, and both function as food and medicinal plants in China and other Asian countries. L. chinense Mill. berries contain multiple mineral and organic compounds (i.e., vitamins $B_{1}, B_{6}, A, C, E$ ), with potential to repair epidermal damage, and showing excellent effects on cardiovascular and cholesterol levels [3,4]. Goji leaves are also a rich source of bioactive compounds that can be used as additive in health-promoting preparation [5,6]. In support of such traditional properties, modern studies indicate that extracts from 
goji berries possess a range of biologic activities, including antioxidant properties [7]. According to Mocan et al. [5], goji fruits have an effect on ageing, neuroprotection, glucose control in diabetics, antioxidant properties, immunomodulation, and antitumor activity, as well as general well-being, fatigue, metabolism, energy expenditure, and cytoprotection. In addition, no harmful substances, such as $\mathrm{NO}_{2}$ and $\mathrm{NO}_{3}$, or the presence of steroids ( $\alpha$-solanine) and tropane alkaloids (skopolamin) have been reported in goji fruit [6]. According to Kulczyński and Gamza-Michałkowska [8], a well-balanced diet and a change in lifestyle have significant impacts in terms of reducing the frequency of diseases in society. Thus, natural antioxidants, particularly in fruits and vegetables, have gained interest among consumers and the scientific community.

Goji shrubs are propagated vegetatively, especially by semi-wooden cuttings and with great success in vitro [9]. According to Dzhugalov et al. [10], the optimum quality fruit can be obtained under hot summer conditions. Rain causes fruit cracking during ripening. Thus, there is a relationship between environmental conditions and the harvest. Optimal growing conditions allow for a production of almost 95,000 tons of fruit annually from August to October. Goji fruit is usually dried, but both fruit and young leaves, which are a valuable source of mineral compounds, can also be eaten raw $[1,11]$. In addition, fruit extracts are used as natural, non-toxic colorants for drinks or cosmetics [12]. In the literature, the main focus has been on the properties of goji fruit. However, the leaves of L. chinense, called "tianjingcao" (vitality and vigor of nature) have rarely been studied, despite their use in traditional Chinese medicine in alleviating mineral deficiency, combating heat distress, quenching thirst, dispelling wind, and enhancing eyesight. Moreover, L. chinense leaves have also been widely used as tea, medicinal vegetables, and herbal drugs in China [5]. Goji leaves contain high amounts of specific flavonoids and phenolic acids, such as chlorogenic acid, quercetin, and rutin. Additionally, goji leaves contain polysaccharides that exert high superoxide and DPPH scavenging abilities, thereby having high antioxidative activity [13]. Information regarding goji leaves, including their chemical composition and bioactive features, is not comprehensive and quite limited. However, recently, L. chinense leaves have been described as a sustainable source of antioxidants and antibacterial compounds.

Considering the excellent health properties and wide use of goji fruit and leaves, we compared the physical-chemical properties of goji leaves and fruit grown in orchard and in vitro culture. In addition, the particular aim of this study was to assess the antimicrobial properties of goji leaves as a scientific basis for the further use of this plant as a functional food/ingredient.

\section{Results and Discussion}

\subsection{Mineral Compound of Leaves and Goji Fruits}

$\mathrm{N}, \mathrm{P}, \mathrm{K}, \mathrm{Ca}, \mathrm{Mg}$ and $\mathrm{Na}$ (i.e., macroelements) are important for several physiological functions. Each of the ingredients plays a specific role in a plant's metabolism. The most important macroelement is nitrogen, a component of amino acids and proteins, DNA and RNA nucleic acids, enzymes, hormones, and energy carriers. Sodium, for example, is a macroelement responsible for membrane depolarization and, water control, and is a physiological cotransporter. Magnesium is required for nucleic acids in protein synthesis. The sodium and magnesium values in dried fruits correspond to $1 / 5$ of the daily human need [14].

The contents $(\mathrm{g} / \mathrm{kg})$ of six macroelements in the leaves of two goji (L. chinense Mill.) cultivars in the samples analyzed are shown in Table 1. The distribution of the compositions of minerals in the different parts of the plant (i.e., fruit or leaves) was determined by the cultivation conditions. In general, the elemental concentrations in all samples decreased in the following order: $\mathrm{N}>\mathrm{K}>\mathrm{Ca}>$ $\mathrm{P}>\mathrm{Mg}>\mathrm{Na}$ and $\mathrm{N}>\mathrm{K}>\mathrm{P}>\mathrm{Ca}>\mathrm{Mg}>\mathrm{Na}$ in the leaves of both cultivars, respectively, from the orchard and in vitro. Among the analyzed macroelements, the highest amount of nitrogen was in the leaves. This high level was found in both varieties grown in the orchard, as well as under the in vitro conditions (Table 1). However, the contents of macroelements such as N, P, and K were significantly higher in plants propagated in vitro compared to plants from the orchard cultivation, despite the high 
content of these components in the soil. Conversely, the contents of $\mathrm{Ca}, \mathrm{Mg}$, and $\mathrm{Na}$ were significantly lower in both cultivars in vitro compared to orchard conditions. The leaves from the New Big cultivar accumulated significantly higher concentrations of $\mathrm{N}, \mathrm{P}, \mathrm{Ca}, \mathrm{Mg}$, and $\mathrm{Na}$. The exception was potassium, which in cultivar No. 1 was higher by $50 \%$ in the orchard and $9 \%$ in vitro. The mineral content of the leaves is also an indicator of a plant's nutrition and condition. There is no information available in the literature about the optimal nutrient content in goji leaves. In this experiment, the recommended values for goji were compared to berry shrubs $[15,16]$. It was found that in the leaves, regardless of growth conditions, there were very low level of $\mathrm{P}$ and $\mathrm{Ca}$. The remaining macroelements were in the optimal range or even exceeded it.

Table 1. Average values of macroelements in leaves and fruit of two cultivars of goji cultivated in orchard and in vitro condition.

\begin{tabular}{ccccccc}
\hline \multirow{2}{*}{$\begin{array}{c}\text { Compounds } \\
(\mathrm{g} / \mathbf{k g})\end{array}$} & \multicolumn{2}{c}{ No. 1 } & \multicolumn{2}{c}{ New Big } & No. 1 & New Big \\
\cline { 2 - 7 } & Orchard & In Vitro & Orchard & In Vitro & Orchard \\
\hline $\mathrm{nyyyyyy} \mathrm{N}\left(22-32^{2}\right)$ & $42.08 \pm 1.71 \mathrm{a}{ }^{1}$ & $57.14 \pm 2.37 \mathrm{~b}$ & $43.50 \pm 1.98 \mathrm{a}$ & $77.92 \pm 3.05 \mathrm{c}$ & $29.85 \pm 1.30 \mathrm{~B}$ & $24.32 \pm 0.92 \mathrm{~A}$ \\
$\mathrm{P}(19-30)$ & $7.85 \pm 0.42 \mathrm{a}$ & $11.93 \pm 0.56 \mathrm{c}$ & $8.52 \pm 0.47 \mathrm{~b}$ & $13.78 \pm 0.51 \mathrm{~b}$ & $5.38 \pm 0.19 \mathrm{~B}$ & $4.85 \pm 0.15 \mathrm{~A}$ \\
$\mathrm{~K}(12-20)$ & $29.57 \pm 1.17 \mathrm{~b}$ & $57.06 \pm 1.98 \mathrm{~d}$ & $14.73 \pm 0.52 \mathrm{a}$ & $52.06 \pm 1.50 \mathrm{c}$ & $4.30 \pm 0.13 \mathrm{~A}$ & $3.98 \pm 0.11 \mathrm{~A}$ \\
$\mathrm{Ca}(4-8)$ & $11.00 \pm 0.52 \mathrm{~b}$ & $3.87 \pm 0.18 \mathrm{a}$ & $11.39 \pm 0.48 \mathrm{~b}$ & $4.00 \pm 0.21 \mathrm{a}$ & $0.91 \pm 0.04 \mathrm{~B}$ & $0.75 \pm 0.03 \mathrm{~A}$ \\
$\mathrm{Mg}(2-4.4)$ & $5.89 \pm 0.17 \mathrm{~b}$ & $2.87 \pm 0.09 \mathrm{a}$ & $7.50 \pm 0.27 \mathrm{c}$ & $3.04 \pm 0.11 \mathrm{a}$ & $1.11 \pm 0.05 \mathrm{~A}$ & $1.02 \pm 0.05 \mathrm{~A}$ \\
$\mathrm{Na}$ (no data) & $4.22 \pm 0.23 \mathrm{c}$ & $2.17 \pm 0.19 \mathrm{~b}$ & $4.60 \pm 0.25 \mathrm{~d}$ & $1.82 \pm 0.13 \mathrm{a}$ & $4.03 \pm 0.19 \mathrm{~B}$ & $3.82 \pm 0.15 \mathrm{~A}$ \\
\hline
\end{tabular}

${ }^{1}$ Means followed by the same letter in lines do not differ significantly at $\mathrm{P}=0.05$ according to Tukey multiple range/small letters for leaves, capital-fruit. ${ }^{2}$ Optimal content for leaves according to Glonek and Komosa [15].

$\mathrm{Fe}, \mathrm{Zn}, \mathrm{Mn}, \mathrm{Cu}$ and Se (i.e., microelements) perform an important function in many biochemical reactions. They are cofactors in enzymatic reactions, such as glucose tolerance factor, and metallo-enzymes in several endogenous reactions, including insulin storage, the immune system, and hormone activators [14,17]. The values obtained for five microelements (i.e., $\mathrm{Fe}, \mathrm{Zn}, \mathrm{Mn}, \mathrm{Cu}$, Se) in the leaves of the two goji cultivars are shown in Table 2. In general, the concentrations of the microelements in all samples decreased in the following order: $\mathrm{Fe}>\mathrm{Mn}>\mathrm{Zn}>\mathrm{Cu}>\mathrm{Se}>\mathrm{Pb}>\mathrm{Ni}$ in the orchard, and $\mathrm{Mn}>\mathrm{Fe}>\mathrm{Zn}>\mathrm{Cu}$ in vitro. It was observed that in leaves of the No. 1 cultivar, these values were higher in comparison to in those of the New Big cultivar. This was opposite to the plants propagated in vitro. Moreover, no heavy metals such as $\mathrm{Pb}, \mathrm{Ni}$, and $\mathrm{Cd}$ were found in the leaves of the plants propagated in vitro. This was due to the absence of these elements in the MS medium. Additionally, in the leaves of goji from the orchard, no Cd was found, although its content in the soil was $0.296 \mathrm{mg} / \mathrm{kg}$. Moreover, 'New Big' in the orchard variety accumulated 38\% more lead in the leaves, while the 'No. 1' accumulated $72 \%$ more nickel in the leaves. This condition can be explained as being due to the mineral variations in the soil and medium, as well as a lower bioaccumulation of these minerals in the leaves. The growing conditions were not the same. Similar to the macroelements, the optimal content of the microelements was compared with the standards for berry shrubs $[15,16]$. Therefore, it was found that in the leaves collected in the orchard, only Mn was at a low level.

The leaves of both tested cultivars of goji contained greater amounts of macro- and microelements and metals than the fruit. Although the leaves were contaminated with more than twice the amount of lead and nickel than the fruit, this was attributed to the orchard being situated close to an industrial site, and therefore potentially being subject to heavy air pollution. Lead is more specific to air pollution than cadmium, and we did not detect it in neither the leaves or the fruit. However, the fruit of the No. 1 cultivar contained 41\% less lead and 33\% more nickel. These values were higher than those obtained by Sá et al. [14] in goji fruit grown in South America and those of Kulaitienè et al. [18] in goji fruit grown in Lithuania. Jeszka-Skowron et al. [19] showed that the presence of Cd was $0.046 \mathrm{mg} / \mathrm{kg}$, $\mathrm{Pb}$ was $0.109 \mathrm{mg} / \mathrm{kg}$, and $\mathrm{Ni}$ was $2.61 \mathrm{mg} / \mathrm{kg}$ in goji fruit. Llorent-Martínez et al. [20] established that $\mathrm{Cd}, \mathrm{Pb}$, and $\mathrm{Ni}$ in goji fruit was $0.035-0.090 \mathrm{mg} / \mathrm{kg}, 0.035-0.095 \mathrm{~g} / \mathrm{kg}$, and $0.33-0.90 \mathrm{mg} / \mathrm{kg}$, respectively. 
According to the Regulation of the European Commission [21], the values defined for fruit by law are 0.05 and $0.20 \mathrm{mg} / \mathrm{kg}$ for $\mathrm{Cd}$ and $\mathrm{Pb}$, respectively. In the present study, the concentrations of toxigenic elements (i.e., $\mathrm{Pb}$ and $\mathrm{Ni}$ ) were low and below the permissible limit levels.

The contents of macroelements in the goji fruit obtained in this study differed from those reported by other authors $[2,14,18,22]$. We did not expect the contents of the studied macroelements to be identical. It was quite difficult to find data for comparison of the same type of leaves and fruit that were investigated in this study. The major macroelements were as follows: $\mathrm{N}>\mathrm{P}>\mathrm{K}>\mathrm{Na}>\mathrm{Mg}$ $>$ Ca for both cultivars (Table 1). Nitrogen is a predominant element (24.32-29.85 g/kg) for the goji fruit of cvs. New Big and No. 1. It was observed that cv. No. 1 had a significantly higher content of macroelements compared to cv. New Big. Significant differences were found between the cultivars in their concentrations of N, P, Ca, and Na. An opposite relationship was observed in the case of the concentrations of microelements in the studied goji fruit (Table 2), in which the major microelements were as follows: $\mathrm{Fe}=\mathrm{Cu}>\mathrm{Zn}>\mathrm{Mn}>$ Se. Ferrum (i.e., iron) was found in the highest concentration in the goji fruit (66.03-79.44 g/kg, with the highest levels in 'No. 1' followed by 'New Big'). The New Big cultivar was characterized by a significantly higher content of microelements in its fruit, except for selenium, which was $25 \%$ lower than in the fruit of the No. 1 cultivar.

Table 2. Average values of microelements in leaves and fruit of two cultivars of goji cultivated in orchard and in vitro conditions.

\begin{tabular}{|c|c|c|c|c|c|c|}
\hline \multirow{3}{*}{$\begin{array}{c}\begin{array}{c}\text { Compounds } \\
(\mathrm{g} / \mathrm{kg})\end{array} \\
\mathrm{Fe}\left(40-60^{2}\right)\end{array}$} & \multicolumn{4}{|c|}{ Leaves } & \multicolumn{2}{|c|}{ Fruit } \\
\hline & orchard & In vitro & Orchard & In vitro & No. 1 & $\begin{array}{l}\text { New Big } \\
\text { ard }\end{array}$ \\
\hline & $120.13 \pm 7.20 c^{1}$ & $71.00 \pm 3.82 a$ & $97.81 \pm 4.07 \mathrm{~b}$ & $77.44 \pm 3.55 a$ & $66.03 \pm 2.04 \mathrm{~A}$ & $79.44 \pm 2.63 B$ \\
\hline $\mathrm{Zn}(8-14)$ & $18.62 \pm 0.35 b$ & $26.77 \pm 0.47 c$ & $14.53 \pm 0.27 a$ & $35.07 \pm 0.31 d$ & $8.16 \pm 0.24 \mathrm{~A}$ & $8.73 \pm 0.19 B$ \\
\hline Mn (70-260) & $50.70 \pm 1.04 b$ & $176.89 \pm 3.57 \mathrm{c}$ & $42.07 \pm 0.88 a$ & $244.64 \pm 5.03 \mathrm{~d}$ & $7.04 \pm 0.12 \mathrm{~A}$ & $7.74 \pm 0.10 \mathrm{~B}$ \\
\hline $\mathrm{Pb}$ & $0.034 \pm 0.03 a$ & n.d. & $0.054 \pm 0.05 b$ & n.d. & $0.017 \pm 0.001 \mathrm{~A}$ & $0.029 \pm 0.002 B$ \\
\hline $\mathrm{Cd}$ & n.d. & n.d. & n.d. & n.d. & n.d. & n.d. \\
\hline $\mathrm{Ni}$ & $0.019 \pm 0.002 b$ & n.d. & $0.011 \pm 0.002 a$ & n.d. & $0.007 \pm 0.001 \mathrm{~B}$ & $0.003 \pm 0.000 \mathrm{~A}$ \\
\hline
\end{tabular}

Our results differ from those obtained by Sá et al. [14], where the concentration of macroelements in goji fruit was within the limits of $3.124-590.7 \mathrm{mg} / \mathrm{kg}$. Additionally, Nascimento et al. [2], Llorent-Martínez et al. [20], and Niro et al. [22] reported slightly different results. As in other plant food, the mineral content of berries reflects the soil in which they are grown. It should be highlighted that the content of required and undesirable elements in the fruit depends largely on the properties of the soil, plant physiology, source and chemical composition of water, fertilizers, pesticides, insecticides, and fungicides used on the plantation. Each species has individual requirements and different tolerance levels to the absorbed and accumulated chemical compounds from the medium [22].

The study of the chemical composition of fruits that are considered to be superfoods is important from nutritional and toxicological perspectives. The percentages of macro- and microelements in the goji fruit were compared to the daily mineral requirements of the human diet [21]. Recommended Daily Allowances (RDAs) have been established, namely, $2 \mathrm{mg}$ of $\mathrm{Cu}, 18 \mathrm{mg}$ of Fe, $400 \mathrm{mg}$ of $\mathrm{Mg}, 2 \mathrm{mg}$ of $\mathrm{Mn}, 1000 \mathrm{mg}$ of P, and $15 \mathrm{mg}$ of $\mathrm{Zn}$ [2]. Niro et al. [22] reported that $100 \mathrm{~g}$ of fresh goji berries can be declared on the label as a source of $\mathrm{Cu}$. The consumption of $100 \mathrm{~g}$ of fresh goji per day contributes to approximately $25 \%$ of the RDA of $\mathrm{Cu}$ [22]. In our study, we obtained similar results, where $100 \mathrm{~g}$ of fresh goji fruit constitutes 30\% and 35\% of the demand for this element, respectively, for the No. 1 and New Big cultivars (Table 2). Moreover, fresh goji fruit is also a rich source of ferrum. One hundred grams constitutes $47 \%$ of the RDA for this element; this was also confirmed by our own research. Copper is involved in maintaining cardiovascular health, and glucose and cholesterol metabolism [23]. Iron is an essential micronutrient due to the fact of its high functionality, while also being an important 
functional food for patients with iron deficiency. In contrast to the results obtained for goji fruit by Niro et al. [22], the fruit we studied were also a small source of selenium. In fact, $100 \mathrm{~g}$ of fresh berries contributed to approximately $13 \%$ and $17 \%$ of the RDA, respectively, for the New Big and No. 1 cultivars. In connection with the use of goji fruit in disease-preventing diets, the results of this study are interesting and very helpful and important. Knowledge of minerals and trace elements in natural products is extremely important. Goji fruit, called functional foods may be a main external source of these nutrients for humans and animals alike.

The analysis carried out using the Ward's method (Figure 1a) identified three groups with similar micro and macroelements in goji. This may indicate that the content of mineral components in leaves and fruits was more dependent on the place of cultivation (in vitro-group a, or orchard-group b). A completely separate group, connected with leaves in a very weak way, was the fruit-group c.

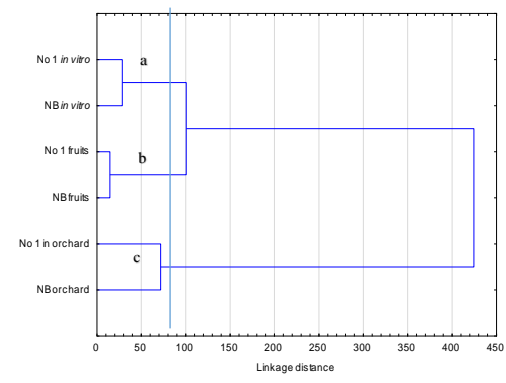

(a)

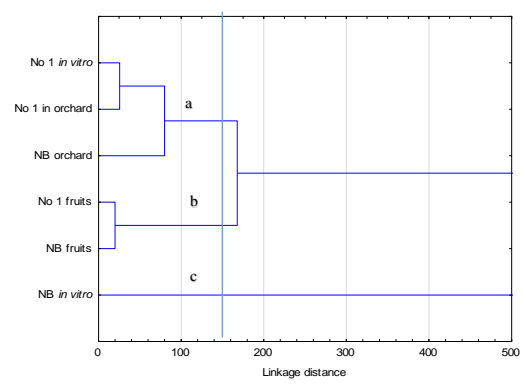

(b)

Figure 1. Dendrogram of cluster analysis of micro- and microelements (a) and polyphenols (b) in two cultivars of goji fruit and leaves (cut off-85 and 150).

\subsection{Leaf and Fruit Color}

According to Kiełbasa and Juliszewski [24], by measuring the area of one leaf, we can determine the intensity of growth and the related intensity of the photosynthesis process. Based on these findings, we can assess the condition of the plants [25]. In this study, the leaf surfaces of the two goji cultivars grown in the orchard and in vitro were compared (Table 3). Upon analyzing the leaves, it was found that the New Big cultivar had the largest leaf area, with a size varying from $4.18 \mathrm{~cm}^{2}$ (orchard) to $2.78 \mathrm{~cm}^{2}$ (in vitro) in comparison to the No. 1 cultivar. The results obtained were similar to those described by Kruczek et al. [6]. The leaves of the plants grown in vitro, despite the fact that they had more mineral components in their composition, that is, they were better nourished, which was also indicated by their more intense color; they were, however, much smaller.

The results of the color determination of the leaves and fruit were also analyzed in the transmitted mode using the photocolorimetric method in the CIE $\mathrm{L}^{*} a^{*} b^{*}$ system. The leaves of L. chinense Mill. were also characterized by a similar value of the green index $[3,6]$. The value of the $a^{*}$ parameter (color ranging from green to red) determined on the surface of leaf ranged from -33.84 to -43.56 (Table 4). The 'New Big' goji leaves under in vitro conditions were $22 \%$ greener compared to the goji leaves grown in the orchard. This could have been influenced by the much higher content of most macro- and microelements in these leaves (Tables 1 and 2). However, the value of the $a^{*}$ parameter in the case of the No. 1 cultivar was at a similar level regardless of the cultivation conditions. The leaves of the New Big cultivar were also darker, which is shown by the lower value of the parameter $\mathrm{L}^{*}(34.57$ and 42.50 , in vitro and orchard, respectively). The value of parameter $L^{*}$ (reaching from 0 to 100 , black to white, respectively) is usually used for tracking color changes [6,26]. However, the goji leaves of cultivar No. 1 were 23\% (in vitro) and 13\% (orchard) brighter compared to the 'New Big' leaves. The color of the leaf surface was determined by parameter $b^{*}$ (from a yellow to a blue color) which ranged from 23.71 ('New Big' in vitro) to 30.63 ('No. 1' orchard). These results are consistent with the Normalized Anthocyanin Index (NAI) ( -1 and +1 , lack of redness and red, respectively). Leaves that were intensely green had the lowest NAI index and ranged from -0.69 ('No. 1' in vitro) to -0.82 ('New Big' orchard). 
On the other hand, the Normalized Difference Vegetation Index (NDVI), which indicates the vegetative potential of plants, was nearly $10 \%$ higher in the goji leaves propagated in vitro (Table 3 ). These results obtained are comparable to those described by Kruczek and Ochmian [3], and Kruczek et al. [6].

Table 3. The leaf area, color measurement and NAI and NDVI value in leaves and fruit of two cultivars of goji cultivated in orchard and in vitro condition.

\begin{tabular}{|c|c|c|c|c|c|c|c|}
\hline \multirow{4}{*}{\multicolumn{2}{|c|}{ Compounds }} & \multicolumn{6}{|c|}{ Cultivar } \\
\hline & & \multicolumn{2}{|c|}{ No. 1} & \multicolumn{2}{|c|}{ New Big } & \multirow[t]{2}{*}{ No. 1} & \multirow[t]{2}{*}{ New Big } \\
\hline & & \multicolumn{4}{|c|}{ Leaves } & & \\
\hline & & Orchard & In Vitro & Orchard & In Vitro & \multicolumn{2}{|c|}{ Orchard } \\
\hline \multicolumn{2}{|c|}{ Leaf area $\left(\mathrm{cm}^{2}\right)$} & $3.53 \pm 0.31 c^{1}$ & $2.11 \pm 0.17 a$ & $4.18 \pm 0.39 d$ & $2.78 \pm 0.15 b$ & - & - \\
\hline 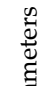 & $\mathrm{L}^{*}$ & $47.82 \pm 2.55 a$ & $42.36 \pm 1.53 b$ & $42.50 \pm 2.71 b$ & $34.57 \pm 1.70 \mathrm{c}$ & $35.88 \pm 1.45 \mathrm{~B}$ & $44.72 \pm 2.04 \mathrm{~A}$ \\
\hline 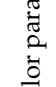 & $a^{*}$ & $-36.27 \pm 3.08 \mathrm{ab}$ & $-38.94 \pm 1.98 b$ & $-33.84 \pm 2.55 a$ & $-43.56 \pm 2.12 c$ & $25.63 \pm 3.24 \mathrm{~A}$ & $33.34 \pm 3.42 \mathrm{~B}$ \\
\hline ن & $b^{*}$ & $30.63 \pm 2.50 c$ & $27.73 \pm 1.45 b c$ & $23.71 \pm 2.26 a$ & $25.25 \pm 1.63 \mathrm{ab}$ & $27.05 \pm 2.44 \mathrm{~A}$ & $41.40 \pm 2.79 B$ \\
\hline \multicolumn{2}{|c|}{ NAI } & $-0.76 \pm 0.10 b$ & $-0.69 \pm 0.06 a$ & $-0.82 \pm 0.07 c$ & $-0.74 \pm 0.05 b$ & $0.62 \pm 0.05 \mathrm{~A}$ & $0.71 \pm 0.05 \mathrm{~B}$ \\
\hline \multicolumn{2}{|c|}{ NDVI } & $0.69 \pm 0.04 a$ & $0.76 \pm 0.05 b$ & $0.84 \pm 0.05 c$ & $0.91 \pm 0.03 d$ & $-0.46 \pm 0.04 \mathrm{~B}$ & $-0.38 \pm 0.03 \mathrm{~A}$ \\
\hline
\end{tabular}

${ }^{1}$ Designation according to Table 1 .

The color of fruit is of crucial importance in consumers' choices. An intensive color may encourage purchases, and/or discourage consumption by warning of their rottenness [6,27,28]. According to Ochmian et al. [26], the color of fruit depends on the place of cultivation and the climatic conditions prevailing there. The color of food products may also change during processing [29]. Regarding the testing of the fruit color, the values of the $a^{*}$ parameter measured were significantly different. The No. 1 cultivar fruit had more than a 23\% red-coloring compared to the 'New Big' fruit (Table 3). Parameter $a^{*}$ was corelated with the NAI [6,26]. The content of anthocyanin pigments determined by the NAI value was responsible for the color of the goji fruit. The NAI showed that the highest anthocyanin contents were recorded in the fruit of the New Big cultivar. When estimating the ripeness and quality of the fruit, the NDVI value was also determined, which in the tested goji fruit, was -0.38 in 'New Big', indicating immature fruit (pre-climacteric). In cultivar No. 1 the value of the NDVI index was -0.46 and characterized fruit with the onset of ethylene production. The obtained results were higher than those described by Kruczek et al. [6].

The color of the surface of the goji fruit skin was described by parameter $b^{*}$. The New Big cultivar contained the highest quantity of red-colored substances (41.40) and a smaller quantity of yellow-colored ones, and these values were in accordance with the values obtained by Kruczek et al. [6]. The value of the $\mathrm{L}^{*}$ parameter was $20 \%$ higher in the New Big cultivar in comparison to the No. 1 cultivar. The results obtained in this study were compared to the results of Lachowicz et al. [28] in saskatoon berries ( $\mathrm{L}^{*}$ from -32.71 to 49.31 ) and Kruczek et al. [6] in goji berries ( $\mathrm{L}^{*}$ from -32.6 to 72.3 ). However, the goji fruit examined by Kruczek and Ochmian [3] and the highbush blueberries examined by Ochmian et al. [30] were darker than in our own research.

\subsection{Polyphenolic Compounds and Health Promoting Capacities}

Polyphenols are secondary metabolites of plants and are generally involved in defense against biotic and abiotic stresses. The content of polyphenols in plants is influenced by many factors, including the degree of maturity at harvest, environmental factors, processing, and storage. In the last decade, there has been great interest in the potential health benefits of dietary plant polyphenols as antioxidants, identifying 10 flavonols, two flavan-3-ols, two tannins, and 10 phenolic acids (Table 4). The two cultivars of goji grown in vitro provided similar values in terms of total phenolic content (102.64 mg/100 g DW and $103.92 \mathrm{mg} / 100 \mathrm{~g}$ DW, 'No.'1 and 'New Big', respectively), while orchard-grown goji had a significantly higher amount $(124.46 \mathrm{mg} / 100 \mathrm{~g} \mathrm{DW}$ and 167.79 mg/100 g DW, 'No. 1' and 
'New Big', respectively). This finding indicates that goji species are a significant source of phenolics. According to Wojdyło et al. [31], the average content of phenol in all goji cultivars grown in Poland was $97.23 \mathrm{mg} / 100 \mathrm{~g}$, with considerable inter-cultivar differences. The content of total polyphenolic compounds was statistically different among the different species. Kiwifruit and apple contained small quantities of polyphenolic compounds (70.23-83.40 mg GAE/100 g FW), while a significantly higher polyphenolic content was observed in strawberry (323.39 mg GAE/100 g FW), and blackcurrant (434.43 mg GAE/100 g FW). The polyphenol content in the tested cultivars of goji was between that of orange (158.70 mg GAE/100 g FW) and guava (310.10 mg GAE/100 g FW). In this study, the dominant phenolic acid was 5-O-caffeoylquinic acid.

Table 4. Content of polyphenolic compounds in leaves and fruit of two cultivars of L. chinensis.

\begin{tabular}{|c|c|c|c|c|c|c|}
\hline \multirow{3}{*}{$\begin{array}{l}\text { Compounds } \\
\text { (mg/100 g DW) }\end{array}$} & \multicolumn{4}{|c|}{ Leaves } & \multicolumn{2}{|c|}{ Fruits } \\
\hline & \multicolumn{2}{|c|}{ No. 1} & \multicolumn{2}{|c|}{ New Big } & \multirow[t]{2}{*}{ No. 1} & \multirow[t]{2}{*}{ New Big } \\
\hline & In Vitro & Orchard & In Vitro & Orchard & & \\
\hline Quercetin-3-O-Gal & n.d. & n.d. & n.d. & n.d. & $0.80 \mathrm{~A}^{1}$ & $2.98 \mathrm{~B}$ \\
\hline Kaempferol-3-O-Glc-7-O-Soph & n.d. & n.d. & $11.47 \mathrm{a}$ & $14.25 b$ & n.d. & n.d. \\
\hline Quercetin-3-O-Rut-7-O-Glu & n.d. & n.d. & n.d. & n.d. & $2.94 \mathrm{~B}$ & $2.07 \mathrm{~A}$ \\
\hline Quercetin-3-O-Soph-7-O-Rha & $12.73 b$ & $14.65 b$ & $4.42 \mathrm{a}$ & $24.03 c$ & $0.24 \mathrm{~A}$ & $2.31 \mathrm{~B}$ \\
\hline Kaempferol-3-O-Rut-7-O-Glu & n.d. & n.d. & n.d. & n.d. & $6.38 \mathrm{~A}$ & $17.22 \mathrm{~B}$ \\
\hline Quercetin-3-O-Glu & n.d. & n.d. & $2.37 \mathrm{~b}$ & $0.72 \mathrm{a}$ & $3.05 \mathrm{~A}$ & $3.50 \mathrm{~A}$ \\
\hline Quercetin-3-O-Rut & $12.58 \mathrm{a}$ & $23.81 \mathrm{~b}$ & $31.42 \mathrm{c}$ & $33.89 \mathrm{c}$ & $11.29 \mathrm{~B}$ & $7.57 \mathrm{~A}$ \\
\hline Quercetin-3-O-Glu-7-O-Rha & $0.22 a$ & $0.48 b$ & $1.04 \mathrm{c}$ & $0.58 \mathrm{~b}$ & n.d. & n.d. \\
\hline Kaempferol-3-O-Rhu & $0.77 \mathrm{a}$ & $0.95 b$ & n.d. & n.d. & 0.18 & n.d. \\
\hline Kaempferol-3-O-Glu-7-O-Rha & $0.68 \mathrm{a}$ & $0.75 \mathrm{a}$ & $1.21 \mathrm{c}$ & $0.94 \mathrm{~b}$ & n.d. & n.d. \\
\hline Total flavonols & $26.98 a$ & $40.64 b$ & $51.93 c$ & $74.41 d$ & $24.88 \mathrm{~A}$ & $35.65 B$ \\
\hline Procyanidin B dimer & $0.99 \mathrm{~b}$ & $3.04 \mathrm{c}$ & $0.49 \mathrm{a}$ & $8.01 \mathrm{~d}$ & $0.62 \mathrm{~A}$ & $0.51 \mathrm{~A}$ \\
\hline$(+)$-Catechin & n.d. & n.d. & $7.38 \mathrm{a}$ & $21.41 b$ & $18.44 \mathrm{~B}$ & $11.04 \mathrm{~A}$ \\
\hline Total flavan-3-ols & $0.99 a$ & $3.04 b$ & $7.87 c$ & $29.42 d$ & $19.06 B$ & $11.55 \mathrm{~A}$ \\
\hline Tetragalloyl-glucose & $0.23 \mathrm{a}$ & $0.29 a$ & $4.22 \mathrm{c}$ & $3.81 \mathrm{~b}$ & n.d. & n.d. \\
\hline Galloylquinic acid & $0.17 \mathrm{a}$ & $0.21 \mathrm{a}$ & $2.55 c$ & $2.09 \mathrm{~b}$ & n.d. & n.d. \\
\hline Total hydrolyzable tannins & $0.40 \mathrm{a}$ & $0.50 \mathrm{a}$ & $6.77 \mathrm{c}$ & $5.9 \mathrm{~b}$ & & \\
\hline 5-O-Ferruloylquinic acid & $0.41 b$ & $0.30 \mathrm{a}$ & 1.77 & $1.60 \mathrm{c}$ & $0.56 \mathrm{~B}$ & $0.21 \mathrm{~A}$ \\
\hline p-Coumaric acid & 1.66 & 1.52 & $2.15 \mathrm{~d}$ & 1.06 & $8.29 \mathrm{~B}$ & $6.35 \mathrm{~A}$ \\
\hline Caffeic acid & $0.64 b$ & $0.82 \mathrm{c}$ & $0.37 \mathrm{a}$ & $0.34 \mathrm{a}$ & n.d. & n.d. \\
\hline Caftaric acid & n.d. & n.d. & n.d. & n.d. & $0.74 \mathrm{~A}$ & $5.06 \mathrm{~B}$ \\
\hline p-Coumaroyl acid dihexoside & n.d. & n.d. & n.d. & n.d. & $4.22 \mathrm{~B}$ & $3.50 \mathrm{~A}$ \\
\hline 3-O-Caffeoylquinic acid (neochlorogenic acid) & $0.51 \mathrm{c}$ & $0.56 \mathrm{c}$ & $0.38 \mathrm{~b}$ & $0.27 \mathrm{a}$ & $4.11 \mathrm{~A}$ & $11.04 \mathrm{~B}$ \\
\hline 3-O-Caffeoylquinic acid derivative & $1.33 \mathrm{~d}$ & $1.12 \mathrm{c}$ & $0.17 \mathrm{a}$ & $0.33 b$ & $10.24 \mathrm{~B}$ & $8.22 \mathrm{~A}$ \\
\hline 4-O-Caffeoylquinic acid (cryptochlorogenic acid) & $0.44 b$ & $0.58 \mathrm{c}$ & $0.20 \mathrm{a}$ & $1.87 \mathrm{~d}$ & n.d. & n.d. \\
\hline 5-O-Caffeoylquinic acid (chlorogenic acid) & $66.47 \mathrm{c}$ & $73.05 \mathrm{~d}$ & $31.04 \mathrm{a}$ & $52.15 b$ & n.d. & n.d. \\
\hline 5-O-Caffeoylquinic acid isomer & $2.81 \mathrm{~d}$ & $2.33 c$ & $1.27 \mathrm{~b}$ & $0.44 \mathrm{a}$ & $2.52 \mathrm{~A}$ & $4.21 \mathrm{~B}$ \\
\hline Total phenolic acids & $71.56 c$ & $77.64 c$ & $33.06 a$ & $55.06 b$ & $21.09 A$ & $26.97 A$ \\
\hline TOTAL & $102.64 \mathrm{~A}$ & $124.46 \mathrm{~B}$ & $103.92 \mathrm{~A}$ & $167.79 \mathrm{C}$ & $74.62 \mathrm{~A}$ & $85.79 \mathrm{~B}$ \\
\hline
\end{tabular}

${ }^{1}$ Designation according to Table 1.

According to Sato et al. [32] and Kruczek et al. [6], chlorogenic acid has a significant influence on the flavor of fruit and vegetables. Moreover, it shows anticarcinogenic, antimutagenic, and antioxidant properties in vitro. In the human body, chlorogenic acid is poorly absorbed and metabolized by colonic microflora [32]. In this study, a significantly higher concentration of chlorogenic acid was detected in the leaves grown in the orchard than in vitro (Table 4). This is in accordance with the results obtained by Chen et al. [13], who also confirmed that in goji fruit the concentration of chlorogenic acid is very low in comparison to the leaves. This demonstrates that goji leaves are a valuable source of chlorogenic acid

Flavonoids, belonging to polyphenolic compounds, are also commonly found in plants, especially in fruit and vegetables [33]. The total amount of flavonoids in the flavonoid fraction was higher in the goji leaves than in the fruit. Moreover, quercetin-3-O-Gal and quercetin-3-O-Rut-7-O-Glu, which were present in the fruit, were not identified in the leaves of both cultivars. On the contrary, kaempferol-3-O-Glc-7-O-Soph, quercetin-3-O-Rut-7-O-Rha, and kaempferol-3-O-Glc-7-O-Rha were only identified in the leaves of both cultivars (Table 5).

For human health, gallotannins are essential [6]. The highest content of tetragalloyl-glucose, regardless of the cultivation method, was found in 'New Big' (4.22 and $3.81 \mathrm{mg} / \mathrm{g} \mathrm{DW}$, in vitro 
and orchard, respectively). In 'No. 1', these values were $95 \%$ and $92 \%$ lower in vitro and in orchard, respectively.

According to many authors $[6,33,34]$, the higher the content of total polyphenols, the higher the antioxidant activity. Pandey and Rizvi [34] suggested that the long-term use of diets rich in plant polyphenols provides some protection against the development of cancer, cardiovascular diseases, diabetes, osteoporosis, and neurodegenerative diseases.

\subsection{Antioxidant Activity}

The antioxidant activity was evaluated using DPPH scavenging activity and ferric-reducing antioxidant power (FRAP). Free radicals are known to be a major factor in biological damage. The DPPH radical-scavenging assay is a widely used method to evaluate the ability of plant extracts to scavenge free radicals generated from the DPPH reagent. The DPPH free radical scavenging activity of the two tested goji cultivars is presented in Table 5. Relatively higher DPPH scavenging abilities were recorded in goji fruit (7.61 mmol Trolox/100 g and $5.33 \mathrm{mmol}$ Trolox/100 g, 'No. 1' and 'New Big', respectively), while the lowest DPPH scavenging abilities were found in the leaves grown in the orchard (3.26 mmol Trolox/100 g, 2.48 mmol Trolox/100 g, 'No. 1' and 'New Big', respectively).

The analysis carried out using the Ward method (Figure 1b) showed that the polyphenol content was divided into three groups with similar micro- and macroelements in goji. The fruits formed a separate group (b), and similar for the leaves of New Big cultivar (c).

Table 5. Health-promoting capacities of leaves end fruit of two cultivars L. chinensis.

\begin{tabular}{|c|c|c|c|c|c|c|c|}
\hline \multirow{2}{*}{\multicolumn{2}{|c|}{ Nutritional Value }} & \multicolumn{4}{|c|}{ Leaves } & \multicolumn{2}{|c|}{ Fruit } \\
\hline & & In Vitro & Orchard & In Vitro & Orchard & \multicolumn{2}{|c|}{ Orchard } \\
\hline \multicolumn{2}{|c|}{ DPPH (mmol Trolox/100g) } & $3.88 c^{1}$ & $3.26 \mathrm{~b}$ & $4.25 \mathrm{~d}$ & $2.48 \mathrm{a}$ & $7.61 \mathrm{~B}$ & $5.33 \mathrm{~A}$ \\
\hline \multicolumn{2}{|c|}{ FRAP (mmol Trolox/100g) } & $4.02 \mathrm{c}$ & $2.54 \mathrm{a}$ & $5.89 \mathrm{~d}$ & $3.48 b$ & $2.89 \mathrm{~A}$ & $3.93 \mathrm{~B}$ \\
\hline \multicolumn{2}{|c|}{$\alpha$-amylase IC50 (mg/mL) } & $112.6 \mathrm{~b}$ & $75.1 \mathrm{a}$ & $172.9 \mathrm{~d}$ & $134.0 \mathrm{c}$ & $33.45 \mathrm{~A}$ & $37.01 \mathrm{~A}$ \\
\hline \multirow[t]{6}{*}{ Soluble sugars (g/100 g DW) } & glucose & $1.55 \mathrm{c}$ & $0.51 \mathrm{a}$ & $1.88 \mathrm{~d}$ & $1.04 \mathrm{~b}$ & $10.11 \mathrm{~A}$ & $13.06 \mathrm{~B}$ \\
\hline & sucrose & $0.20 \mathrm{~b}$ & $0.24 \mathrm{c}$ & $0.18 b$ & $0.12 \mathrm{a}$ & $0.51 \mathrm{~A}$ & $0.77 \mathrm{~B}$ \\
\hline & oxalic acid & $0.021 \mathrm{a}$ & $0.024 \mathrm{a}$ & $0.073 b$ & $0.080 \mathrm{~b}$ & n.d. & 0.362 \\
\hline & citric acid & $0.115 b$ & $0.292 \mathrm{c}$ & $0.083 a$ & $0.314 \mathrm{~d}$ & $0.951 \mathrm{~A}$ & $1.485 \mathrm{~B}$ \\
\hline & succinic acid & $0.027 \mathrm{ab}$ & $0.035 \mathrm{bc}$ & $0.021 \mathrm{a}$ & $0.042 \mathrm{c}$ & $0.547 \mathrm{~B}$ & $0.322 \mathrm{~A}$ \\
\hline & fumaric acid & $0.019 b c$ & $0.023 c$ & $0.016 \mathrm{ab}$ & $0.014 \mathrm{a}$ & $0.078 \mathrm{~B}$ & $0.066 \mathrm{~A}$ \\
\hline
\end{tabular}

${ }^{1}$ Designation according to Table 1.

Regarding the values of the total antioxidant capacity, expressed as the FRAP assay, the results showed large statistical variations among the tested cultivars. The highest radical scavenging activity (FRAP) was obtained in the goji leaves grown in vitro (4.02 mmol Trolox/100 $\mathrm{g}$ and $5.89 \mathrm{mmol}$ Trolox/100 g, 'No. 1' and 'New Big', respectively); meanwhile, the FRAP values obtained for the leaves grown in the orchard and for fruit were at a similar level (Table 5). Our data agree with that reported by Kruczek et al. [6] and Wojdyło et al. [31], who demonstrated similar values of antioxidant activity in their studies. According to many authors [6,26,31], the antioxidant activity of various plant species (fruit or leaves) may be determined by growing conditions, geographical location, climatic conditions, genotype, fruit maturity, or even the collection methods. Many authors have highlighted that fruit rich in significant amounts of phytochemicals are of great interest to potential consumers [6,13].

\subsection{Antidiabetic Activity of Goji Fruits}

The inhibition of $\alpha$-amylase in the analyzed leaves ranged from 75.1 ('No. 1 ' in the orchard) to $172.9 \mathrm{mg} / \mathrm{mL} \mathrm{IC}_{50}$ ('New Big' in vitro), and in the fruits ranged from $33.45 \mathrm{mg} / \mathrm{mL} \mathrm{IC} 50$ in 'No. 1' to $37.01 \mathrm{mg} / \mathrm{mL} \mathrm{IC}_{50}$ in 'New Big'. While the inhibition of $\alpha$-glucosidase in leaves samples was between 22.05 ('No. 1') and $42.28 \mathrm{mg} / \mathrm{mL} \mathrm{IC}_{50}$ ('New Big'). Goji leaf extracts collected in vitro were more 
effective in the activity of $\alpha$-amylase and $\alpha$-glucosidase inhibitors (Table 5). However, there were no statistical differences in the activity of $\alpha$-amylase and $\alpha$-glucosidase in fruits. The inhibition of these enzymes may be effective for regulating type 2 diabetes by controlling the absorption of glucose [35]. Both $\alpha$-amylase and $\alpha$-glucosidase inhibitory activity in fruits such as pomegranate, strawberry, raspberry, pear, kiwi, plum, lingonberry, black currant, and blueberry extracts has been confirmed in other studies $[16,28,31,35]$. Inhibition of these enzymes is specifically useful in the treatment of non-insulin-dependent diabetes, as it slows down glucose release into the bloodstream [31].

\subsection{Soluble Sugars and Organic Acid}

The organoleptic properties of the fruit are influenced by many ingredients, including sugars and organic acids [31]. The sugar content in the goji samples examined in this study is presented in Table 5. The main sugars identified in the analyzed leaves and fruit of the two cultivars of goji were fructose, glucose, and sucrose. The largest amounts of total sugars were fructose and glucose, both in the leaves (0.89-2.51 g/100 g DW and 0.51-1.88 g/100 g DW, fructose and glucose, respectively) and the fruit (9.67-11.83 g/100 g DW and 10.11-13.06 g/100 g DW, fructose and glucose, respectively). The cultivar with the highest sugar content in both its leaves and fruit was 'New Big'. Moreover, the leaves from goji grown in vitro had from $80 \%$ to a $120 \%$ higher total sugar amount than in the leaves grown in the orchard. This may be due to the addition of $3 \%$ sucrose to the MS medium.

Our results show significant differences $(p<0.05)$ in the content of organic acids among the tested cultivars (Table 5). The total organic acid content ranged from 0.182 to $0.450 \mathrm{~g} / 100 \mathrm{~g}$ DW in the leaves and from $1.576 \mathrm{~g} / 100 \mathrm{~g}$ DW in 'No. 1' fruit to $2.235 \mathrm{~g} / 100 \mathrm{~g}$ DW in 'New Big' fruit. The New Big cultivar had the highest amount of organic acid, and it was also observed that leaves from goji grown in vitro were the lowest. Oxalic, citric, succinic, and fumaric acids were the main organic acids in the leaves and fruit. However, in the fruit from 'No. 1', oxalic acid was not detected. The highest amount of total organic acid was found to be citric acid, both in the leaves and the fruit. Other organic acids, (i.e., oxalic, succinic, and fumaric) were present in low concentrations. The types and amounts of sugars and organic acids were the same as reported by Montensano et al. [36] and Wojdyło et al. [31]. According to Potterat [1], the content of polysaccharides and total sugars in L. chinensis fruit is a major medicinal aspect of goji berries. The sugar/acidity ratio in fruit is an important choice for consumers.

PCA for minerals and phytochemical content of leaves and fruits explained (70.94) the total variance, where PC1 represented $45.30 \%$ and PC2 25.64\% (Figure 2). The statistical method pointed out three major parts. Our results show that there were many correlations (positive, negative, weak) between antioxidant capacity and mineral extractability. The first group included polyphenols, which showed high dependence with antioxidant activity, and inhibitors activities. It is known that the antioxidant activity of fruits is influenced by their phenolic composition [37]. There was a positive correlation between the DPPH values and polyphenolic compounds content, meaning that the concentration of phenolic compounds may be a good indicator of the reducing capacity in the fruits. Polyphenolic compounds such as phenolic acids, flavonoids, anthocyanidins, and tannins, produced as secondary metabolites by plants, possess remarkable antioxidant and immunomodulatory activities [38]. A high correlation between polyphenols and NDVI index was also found. It was also found that macroelements (especially $\mathrm{K}, \mathrm{P}$, and $\mathrm{N}$ ) were negatively correlated with microelements. This may be due to synergism and antagonism between minerals. It is well known, for example, that high phosphorus content may limit the uptake of microelements. A high content of these elements was found in the soil (Table 7) and leaves (Tables 1 and 2) of the studied goji cultivars. There is also antagonism between $\mathrm{Cu}$ and $\mathrm{Zn}$, and potassium strongly limits the uptake of $\mathrm{Na}$. In contrast, potassium shows strong synergy with nitrogen. There may also be an overaccumulation of some components in the soil (e.g., phosphorus and potassium) and depletion of others (magnesium and microelements). 


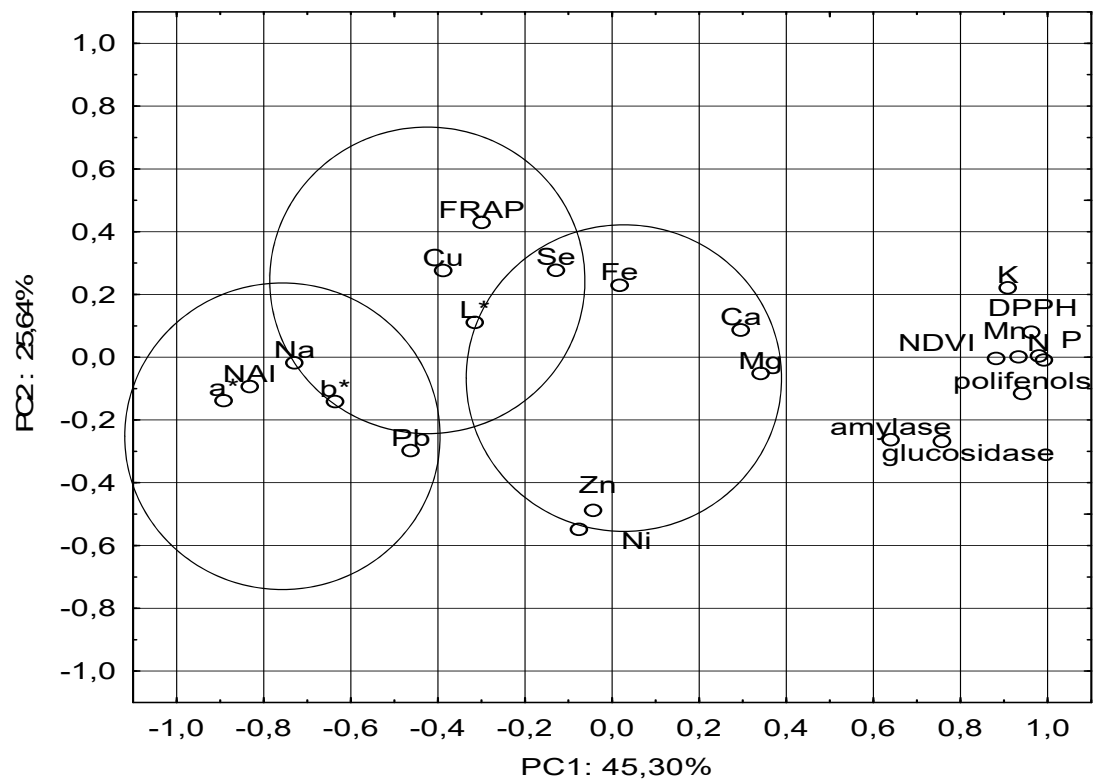

Figure 2. The principal component analysis (PCA) for mineral compositions and phytochemical content of goji leaves and fruit depending on growth conditions.

In the second group, a correlation between FRAP and some microelements. Generally, positive correlations were observed between FRAP and $\mathrm{Fe}, \mathrm{Cu}$, and $\mathrm{Sn}$ content in our research. These results demonstrate that FRAP in fruits has a significant impact on enhancing the extractability of $\mathrm{Cu}$ bound with the ability to form chelated metal ions by FRAP and to retain them (37). Antioxidants that react in the FRAP assay are those that can reduce, under the reaction conditions used, the $\mathrm{Fe}^{3+}$-TPTZ salt to Fe2+-TPTZ form. These include polyphenolic compounds such as catechins and other flavonoids in plant-based foods [39].

In the third group, the dependency between NAI index and color parameters $a^{*}$ and $b^{*}$ was visible.

No anthocyanins were found in the polyphenolic profile of goji, as evidenced by the negative value of the NAI index (also a color indicator-Table 3). This is confirmed by high dependence on other parameters of color $\mathrm{a} *$ and $\mathrm{b} *$ and $\mathrm{Mg}$, the basic component of chlorophyll. This correlation may indicate that the presence or absence of one metal has no effect on the other.

\subsection{Antimicrobial Activity}

Plants are an important source of potentially useful structures for the development of new chemotherapeutic agents. In vitro antimicrobial activity should be determined first [40]. The leaf extracts in the tested concentrations showed inhibitory activity (MIC) on the growth of the analyzed Gram-positive bacteria, especially on S. aureus. However, among the Gram-negative bacteria, only P. vulgaris was sensitive to its effects (Table 6). A definitely higher inhibitory effect characterized extracts from the leaves collected from the shrubs that grew in the orchard, especially from the New Big cultivar. The antimicrobial activity of the leaf extracts has been confirmed in studies conducted with the use of the disc diffusion method (Table 6). Extracts from the leaves harvested in the orchard of both studied cultivars had a higher inhibition zone $(9.0-16.7 \mathrm{~mm})$ compared to the in vitro leaves (8.6-14.2 mm). The smallest inhibition diameter was determined for Gram-negative E. coli $(8.6 \mathrm{~mm})$ and the largest $(16.7 \mathrm{~mm})$ for Gram-positive bacteria such as B. subtilis. However, these inhibition capacities are lower than those observed by Mocan et al. [5] and Dahech et al. [41]. 
Table 6. Antibacterial activity and Minimal Inhibitory Concentration of leaves extracts and antibiotics against bacterial species tested by disc diffusion assay.

\begin{tabular}{|c|c|c|c|c|c|c|c|c|c|}
\hline \multirow{4}{*}{ Bacterial Strains } & \multicolumn{9}{|c|}{ Inhibition Zone-IZ $(\mathrm{mm})$ and Minimal Inhibitory Concentration-MIC $(\mu \mathrm{g} / \mathrm{mL})$} \\
\hline & \multicolumn{4}{|c|}{ No. 1} & \multicolumn{4}{|c|}{ New Big } & \multirow[t]{3}{*}{$\begin{array}{c}\text { Standard Antibiotic } \\
\text { (Gentamicin) }\end{array}$} \\
\hline & \multicolumn{2}{|c|}{ Orchard } & \multicolumn{2}{|c|}{ In Vitro } & \multicolumn{2}{|c|}{ Orchard } & \multicolumn{2}{|c|}{ In Vitro } & \\
\hline & IZ & MIC & IZ & MIC & IZ & MIC & IZ & MIC & \\
\hline E. coli & $9.6 \pm 0.9$ & $>100$ & $8.6 \pm 0.6$ & $>100$ & $10.5 \pm 0.8$ & 100 & $9.8 \pm 0.8$ & $>100$ & 12.5 \\
\hline P. vulgaris & $12.2 \pm 0.8$ & 75 & $11.3 \pm 0.9$ & 75 & $14.3 \pm 0.8$ & 50 & $13.5 \pm 0.9$ & 100 & 17.0 \\
\hline L. monocytogenes & $10.3 \pm 0.8$ & 100 & $10.2 \pm 0.7$ & $>100$ & $10.9 \pm 0.9$ & 75 & $10.5 \pm 0.4$ & $>100$ & 18.6 \\
\hline
\end{tabular}

\section{Materials and Methods}

\subsection{Characteristics of the Research Area}

\subsubsection{Orchard Experiment}

The study was carried out in the Department of Horticulture and the Department of Plant Genetics, Breeding and Biotechnology, of the West Pomeranian University of Technology in Szczecin. The research station is located in subzone 7A in the North-Western part of Poland in the Szczecin Lowland at a distance of approximately $65 \mathrm{~km}$ from the Baltic Sea (53 $\left.40^{\prime} \mathrm{N}, 14^{\circ} 88^{\prime} \mathrm{E}\right)$. The research was conducted at a production plantation specializing in the cultivation of highbush blueberry, located in the Szczecin's Lowland. In this area, there are numerous hills of 40-60 m a.s.l., the remnants of the frontal moraine. The climate of this area is also significantly affected by the presence of big water basins (Szczecin Lagoon, Dabie Lake, the Odra River), which provide additional moisture in the period of plant vegetation. The average growing season (April-October) temperature from 1951 was $13.7^{\circ} \mathrm{C}$ and rainfall $391 \mathrm{~mm}$ [42].

\subsubsection{In Vitro Experiment}

The second part of the experiment was carried out in the Laboratory of In vitro Cultures, where all cultures were incubated in a growth room at a temperature of $24 \pm 2{ }^{\circ} \mathrm{C}$ under a $16 \mathrm{~h}$ photoperiod with a photosynthetic photon flux density (PPFD) of $40 \mu \mathrm{mol} / \mathrm{m}^{2} / \mathrm{s}$ provided by Narva (Germany) emitting daylight cool white.

\subsection{Characteristics of the Plant Material}

\subsubsection{Orchard Experiment}

The soil ( $\mathrm{pH}$ 6.75) in the orchard was an agricultural soil with a natural profile, developed from silt loam (sand $42.7 \%$, silt $52.9 \%$, clay $4.4 \%$ ) with a considerably lower density of $1.23 \mathrm{Mg} / \mathrm{m}^{3}$. The groundwater level was $140-160 \mathrm{~cm}$, and a higher water capacity of $46.2 \% \mathrm{ww}$. It also contained much more organic matter- $32.4 \mathrm{~g} / \mathrm{kg}$ of soil. Regardless of the site, the soil was characterized by similarly low salinity EC $0.33-0.42 \mathrm{mS} / \mathrm{cm}$. The mineral content of the soil is shown in Table 7 . The soil, in which the shrubs grew, regardless of the stand, in comparison to the optimal mineral content of the soil by Sadowski et al. [43], was characterized by a high content of $\mathrm{P}, \mathrm{K}$, and Mg. Every spring nitrogen fertilization was used at a dose of $45 \mathrm{~kg}$ N. Irrigation of the plantation was carried out annually using a permanently installed T-Tape drip irrigation line with the emitter's performance of $1.5 \mathrm{~L} / \mathrm{h}$ ( $3 \mathrm{~L}$ of water on a section of 1 linear meter of the installation). The moisture content of the soil was maintained in the PF 1.8-2.1 range and was determined using contact tensiometers. 
Table 7. Mineral composition of soil in which the two goji cultivars grew in orchard.

\begin{tabular}{|c|c|c|c|c|c|c|c|c|c|c|c|c|c|}
\hline $\mathbf{N}$ & $\mathbf{P}$ & $\mathbf{K}$ & $\mathrm{Mg}$ & $\mathrm{Ca}$ & $\mathrm{Na}$ & $\mathrm{Fe}$ & Mn & $\mathrm{Zn}$ & $\mathrm{Cu}$ & $\mathrm{Cd}$ & $\mathrm{Pb}$ & $\mathrm{Ni}$ & Se \\
\hline $\mathrm{g} / \mathrm{kg}$ & & & & & & & $\mathrm{mg} / \mathrm{kg}$ & & & & & & \\
\hline 17.33 & 123.3 & 284.7 & 72.7 & 452 & 11.3 & 83.4 & 57.3 & 37.0 & 7.52 & 0.296 & 31.3 & 4.67 & 0.031 \\
\hline
\end{tabular}

\subsubsection{In Vitro Experiment}

The research material consisted of 15-20 $\mathrm{mm}$ stem nodes with an axillary bud of goji obtained from a sterile stabilized in vitro culture. The explants were transferred to MS medium according to Murashige and Skoog's [44] composition of vitamins, and macro- and microelements. All media contained $30 \mathrm{~g} / \mathrm{dm}^{3}$ of sucrose (Chempur, Poland) and $100 \mathrm{mg} / \mathrm{dm}^{3}$ of myoinositol (Duchefa, The Netherlands) and were solidified with $8 \mathrm{~g} / \mathrm{dm}^{3}$ of agar (Biocorp, Poland). The $\mathrm{pH}$ of the media was adjusted to 5.7 . The media were heated and then $30 \mathrm{~mL}$ was poured into $450 \mathrm{~mL}$ flasks, which were autoclaved at $121^{\circ} \mathrm{C}(0.1 \mathrm{MPa})$ during the time required according to the volume of medium in the vessels. After the end of the experimental period (five weeks), the explants were removed and washed with deionized distilled water.

\subsection{Analysis of the Chemical Compounds}

For the chemical analyses, leaves were taken from the orchard at the beginning of August (during harvesting of the fruit); 100 pieces were taken from each combination. Typical, healthy leaves from the middle part of the annual shoots were collected. Leaves were taken from the multiplied 5-week shoot cultures of goji plants, to be used for chemical analyses. From each harvest, we also took samples of fruits that were then frozen. After finishing the harvest from each period, we prepared a collective sample that was dried (and $65^{\circ} \mathrm{C}$ ) and ground.

The content of elements in leaves and fruits were determined after mineralization: $\mathrm{N}, \mathrm{P}, \mathrm{K}, \mathrm{Ca}$, and $\mathrm{Na}$ were measured after wet mineralization in $\mathrm{H}_{2} \mathrm{SO}_{4}(96 \%)$ and $\mathrm{HClO}_{4}(70 \%)$. The content of $\mathrm{Cu}$, $\mathrm{Zn}, \mathrm{Mn}, \mathrm{Fe}$, Se were determined after mineralization in $\mathrm{HNO}_{3}(65 \%)$ and $\mathrm{HClO}_{4}(70 \%)$ in a ratio soil 1:1 [45], leaves and fruits 3:1 [46]. The total $\mathrm{N}$ concentration in plants was determined by the Kjeldahl distillation method [47]. The content of $\mathrm{K}$ was measured with the atomic emission spectrometry, $\mathrm{Mg}$, $\mathrm{Ca}, \mathrm{Na}, \mathrm{Cu}, \mathrm{Zn}, \mathrm{Mn}, \mathrm{Se}, \mathrm{Fe} \mathrm{Pb}, \mathrm{Ni}$, and $\mathrm{Cd}$ content with the flame atomic absorption spectroscopy. P was assessed by the colorimetric method [16]. All tests were performed each year in three replications.

\subsection{Nutritional Value and Polyphenols of Leaves and Fruits}

Samples (leaves and fruit) were freeze-dried before the analysis, and then powdered and subjected to the extraction process according to the methodology of Oszmiański et al. [48]. Nutritional value was determined in the dehydrated and leaves and fruit. Soluble sugars and organic acids were determined according to the procedure described by Dias et al. [49]. Soluble sugars and organic acids were determined by UFLC-PDA.

The FRAP (Ferric-Reducing Antioxidant Power) assay was done according to Benzie and Strain [50] and the 1,1-diphenyl-2-picrylhydrazyl (DPPH) was done according to Shimada et al. [51]. The antioxidant capacity is expressed as Trolox equivalent. The absorbance at $517 \mathrm{~nm}$ was determined by spectrophotometer UV-2401 PC. In goji leaves and fruit extracts, polyphenol identification in UPLC-PDA-ESI-MS/MS (ultra-performance liquid chromatography with photodiode array and electrospray ionization tandem mass spectrometry detection) was executed using an ACQUITY Ultra Performance LC system appointed with a binary solvent manager, a photodiode array detector (Waters Corporation, Milford, MA, USA) and a G2 Q-TOF micro mass spectrometer (Waters, Manchester, $\mathrm{UK}$ ) equipped with an electrospray ionization (ESI) source operating in both negative and positive modes [52]. 


\subsection{Antidiabetic Activity ( $\alpha$-Amylase, $\alpha$-Glucosidase)}

The activity of the parasite and host extracts was assayed according to the procedure described previously by Podsedek et al. [35] ( $\alpha$-glucosidase) and Nickavar and Yousefian [53] ( $\alpha$-amylase). All samples were assayed in triplicate and the result was expressed as IC50. The amount of the inhibitor (expressed as mg per $1 \mathrm{~mL}$ of the reaction mixture under assay conditions) required to inhibit $50 \%$ of the enzyme activity is defined as the IC50 value. All samples were assayed in triplicate.

\subsection{Antimicrobial Activity Assay}

The antimicrobial activity of the extracts was evaluated using the agar well diffusion method [54]. Ready-made sterile Petri dishes (Ø $90 \mathrm{~mm}$ ) with a Mueller-Hinton medium were used. The cell suspensions $(100 \mu \mathrm{L})$ were evenly distributed on the Petri dishes. Six-millimeter wells were punched into the agar with a sterile Pasteur pipette, in which $60 \mu \mathrm{L}$ of the extracts was applied. Gentamycin was used as a control for bacteria. The dishes were incubated at $37^{\circ} \mathrm{C}$ for $24 \mathrm{~h}$. The antimicrobial activity was evaluated by measuring the diameter of the circular inhibition zones around the well.

For the evaluation of the antimicrobial activity, the following were used: Gram-positive bacteria Staphylococcus aureus (ATCC-25923), Bacillus subtilis (ATCC-12228), and Listeria monocytogenes (ATCC-19115), and Gram-negative: Escherichia coli (ATCC-25922) and Proteus vulgaris 458. The MIC (Minimal Inhibitory Concentration) of the solutions was determined for each strain. The MIC value determines the lowest oil concentration (i.e., 10, 25, 50, 75, and $100 \mu \mathrm{g} / \mathrm{mL}$ ), at which no growth (turbidity) of the tested bacterial strain is visually observed, and at the same time precedes the concentration at which growth is visible. For the above determinations, methodology consistent with Inouye et al. [55] was used.

\subsection{Area of one Leaf $\left(\mathrm{cm}^{2}\right)$}

In autumn, the foliage area (taken from the central part of annual shoots) was measured using the Delta Image Analysis System (Delta-T Devices LTD, England) scanner connected to the computer.

\subsection{Color and Pigment Parameters}

The color parameters assessed were $L^{*}\left(L^{*}=100\right.$ means white; $L^{*}=0$ means black), $a^{*}\left(+a^{*}\right.$ means redness; $-a^{*}$ means greenness), $b^{*}\left(+b^{*}\right.$ means yellow; $-b^{*}$ means blue). Measurements were obtained with an aperture diameter of $3 \mathrm{~mm}$; color was measured in glass cuvettes, through a $10^{\circ}$ observer type and D65 illuminant. CIE L* $a^{*} b^{*}$ (Color Measurement Committee of the Society of Dyers and Colorists) was measured using a spectrophotometer (Konica Minolta CM-700d) [56,57]. The pigment contents are displayed on the screen as normalized difference vegetation index (NDVI) and normalized anthocyanin index (NAI) [58]. The dried plant material was powdered in a laboratory mill in triplicate. About $3 \mathrm{~g}$ of ground plants were poured into the glass cuvette, and 50 measurements were made in triplicate. The samples were mixed before each measurement.

\subsection{Statistical Analysis}

All statistical analyses were performed using Statistica 13.0 (StatSoft Polska, Cracow, Poland). Non-parametric methods (Kruskal-Wallis test) were used if neither the homogeneity of variance nor the normality of distribution had been previously established. The statistical significance of the differences between means was determined by testing the homogeneity of variance and normality of distribution, followed by ANOVA with Tukey's post hoc test. The significance was set at $p<0.05$. To determine the relationship between the cultivars and macro- and microelements, the results obtained were subjected to agglomerative cluster analysis and classified into groups in a hierarchical order by means of the Ward's method. Multivariate analysis was performed by applying principal component analysis (PCA). The data were auto-scaled during pre-processing. 


\section{Conclusions}

The obtained results enrich the knowledge of the composition and nutritional values of fresh goji fruit grown in northeast Europe and will help to verify the information given on the packaging. Differences in the composition of the macro- and microelements of the two goji cultivars No. 1 and New Big, grown in an orchard and under in vitro conditions were shown. These differences resulted mainly from the growing conditions of these shrubs and the composition of the soil. Goji berries cultivated in vitro were confirmed as an important source of healthy compounds, providing a significant contribution to the diet through both its fruit and leaves. The cultivars were rich in macro- and microelements and low in levels of toxigenic elements (i.e., $\mathrm{Pb}$ and $\mathrm{Ni}$ )

The color of the leaves and the NDVI indicated that the plants had optimal nutrient content, so it can be concluded that the assigned norms of the macro- and microelements can be a good indicator of their nutrition.

The results presented in this study provide information that goji berries grown in Poland are an interesting fruit in terms of their important health-promoting contents such as macroand microelements, antioxidants, and anti-microbiological properties, sugars, organic acid, and phenolic acids.

Among the Gram-positive bacteria, B. subtilis proved to be the most sensitive to the extracts, and among the Gram-negative bacteria, it was P. vulgaris. The strongest inhibitory and bactericidal effect (i.e., the lowest MIC values) in relation to the majority of the examined bacteria was found in the extract from the 'New Big' leaves collected in the orchard. Therefore, it can be concluded that the New Big cultivar is a source of active substances that inhibit the growth and development of selected types of bacteria.

The knowledge obtained from this study will help determine the commercial potential of goji berries used for nutraceutical applications and of the incorporation in food preparation that improves human health. Taking into consideration the RDAs for minerals established by the EU, fresh goji fruit can be a source of $\mathrm{Cu}, \mathrm{Fe}, \mathrm{Mn}, \mathrm{Zn}, \mathrm{P}$, and Se.

Author Contributions: Material, A.K., I.O., M.K.-M., conceptualization, A.K., I.O., M.K.-M., methodology, S.L., I.O., M.K.-M., J.O., formal analysis, I.O., A.K., S.L.; writing-original draft preparation, A.K., I.O., M.K.-M., S.L., writing-review and editing, I.O., M.K.-M., J.O., visualization, I.O. All authors have read and agreed to the published version of the manuscript.

Funding: This research was supported by the Polish Ministry of Science and Higher Education Grant no. NN 310205737 and West Pomeranian University of Technology Grant no. 518-07-014-3171-03/18.

Conflicts of Interest: The authors declare no conflict of interest. The funders had no role in the design of the study; in the collection, analyses, or interpretation of data; in the writing of the manuscript, or in the decision to publish the results.

\section{References}

1. Potterat, O. Goji (Lycium barbarum and Lycium chinense): Phytochemistry, pharmacology and safety in the perspective of traditional uses and recent popularity. Planta Med. 2010, 76, 7-19. [CrossRef] [PubMed]

2. Nascimento, A.N.; Silvestre, D.M.; de Oliveira Leme, F.; Nomura, C.S.; Naozuka, J. Elemental analysis of goji berries using axially and radially viewed inductively coupled plasma-opical emissin spectometry. Spectometry 2015, 30, 36-41.

3. Kruczek, A.; Ochmian, I. The influence of shurbs cutting method on yielding and quality of the goji berries (Lycium barbarum L.). Folia Pomeranae Univ. Technol. Stetin. Agric. Aliment. Piscaria Zootech. 2016, 330, 131-138. [CrossRef]

4. Dănăilă-Guidea, A.M.; Dobrinoiu, R.-V.; Vişan, L.; Toma, R.C. Protocol for efficient in vitro multiplication of Lycium barbarum L. (Goji) by direct organogenesis. Sci. Bull. Ser. F Biotechnol. 2015, 19, 34-38. 
5. Mocan, A.; Zengin, G.; Simirgiotis, M.; Schafberg, M.; Mollica, A.; Vodnar, D.C.; Rohn, S. Functional constituents of wild and cultivated Goji (L. barbarum L.) leaves: Phytochemical characterization, biological profile, and computational studies. J. Enzym. Inhib. Med. Chem. 2017, 32, 153-168. [CrossRef] [PubMed]

6. Kruczek, A.; Ochmian, I.; Krupa-Małkiewicz, M.; Lachowicz, S. Comparison of morphological, antidiabetic and antioxidant properties of goji fruits. Acta Univ. Cibiniensis Ser. E Food Technol. 2020, 24,1-14. [CrossRef]

7. Chang, R.C.C.; So, K.F. Use of anti-aging herbal medicine, Lycium barbarum, against aging-associated diseases. What do we know so far? Cell. Mol. Neurobiol. 2008, 28, 643-652. [CrossRef]

8. Kulczyński, B.; Gramza-Michałowska, A. Goji berry (Lycium barbarum): Composition and health effects-a review. Pol. J. Food Nutr. Sci. 2016, 66, 67-76. [CrossRef]

9. Osman, N.I.; Awal, A.; Sidik, N.J.; Abdullah, S. In vitro regeneration and antioxidant properties of Lycium barbarum L. (goji). J. Teknol. 2013, 62, 35-38.

10. Dzhugalov, H.; Lichev, V.; Yordanov, A.; Kaymakanov, P.; Dimitrova, V.; Kutoranov, G. First results of testing Goji berry (Lycium barbarum L.) in Plovdiv region, Bulgaria. Sci. Pap. Ser. B Hortic. 2015, 59, 47-50.

11. Kruczek, A.; Krupa-Małkiewicz, M.; Ochmian, I. The influence of shrubs cutting method on yielding and quality of the goji berries (Lycium barbarum L.). Folia Pomeranae Univ. Technol. Stetin. Agric. Aliment. Piscaria Zootech. 2017, 336, 67-74. [CrossRef]

12. Bogacz, K. Goji-Fruit of health and longevity. PFiOW 2009, 9, 33-34.

13. Chen, P.Y.; Shih, T.H.; Chang, K.C.; Wang, J.S.; Yang, C.M.; Chang, Y.S. Potential of galled leaves of Goji (Lycium chinense) as functional food. BMC Nutrition. 2020, 6, 1-10. [CrossRef] [PubMed]

14. Sá, R.R.; da Cruz Caldas, J.; de Andrade Santana, D.; Lopes, M.V.; dos Santos, W.N.L.; Korn, M.G.A.; Júnior, A.D.F.S. Multielementar/centesimal composition and determination of bioactive phenolics in dried fruits and capsules containing Goji berries (Lycium barbarum L.). Food Chem. 2019, 273, 15-23.

15. Glonek, J.; Komosa, A. Fertigation of highbush blueberry (Vaccinium corymbosum L.). Part I. The effect on growth and yield. Acta Sci. Pol. Hortorum Cultus 2013, 12, 47-57.

16. Ochmian, I.; Malinowski, R.; Kubus, M.; Malinowska, K.; Sotek, Z.; Racek, M. The feasibility of growing highbush blueberry (V. corymbosum L.) on loamy calcic soil with the use of organic substrates. Sci. Hort. 2019, 257, 108690. [CrossRef]

17. Maret, W. The metals in the biological periodic system of the elements: Concepts and conjectures. Int. J. Mol. Sci. 2016, 17, 66. [CrossRef]

18. Kulaitienė, J.; Vaitkevičienè, N.; Jarienė, E.; Černiauskienė, J.; Jeznach, M.; Paulauskienè, A. Concentrations of minerals, soluble solids, vitamin $\mathrm{C}$, carotenoids and toxigenic elements in organic goji berries (Lycium barbarum L.) cultivated in Lithuania. Biol. Agric. Hortic. 2020, 36, 130-140. [CrossRef]

19. Jeszka-Skowron, M.; Zgoła-Grześkowiak, A.; Stanisz, E.; Waśkiewicz, A. Potential health benefits and quality of dried fruits: Goji fruits, cranberries and raisins. Food Chem. 2017, 221, 228-236. [CrossRef]

20. Llorent-Martínez, E.J.; Córdova, M.L.F.-D.; Ortega-Barrales, P.; Ruiz-Medina, A. Characterization and comparison of the chemical composition of exotic superfoods. Microchem. J. 2013, 110, 444-451. [CrossRef]

21. European Commission. Regulation EU. No 1169/2011 of the European Parliament and of the Council of 25 October 2011 on the provision of food information to consumers. Off. J. Eur. Union 2011, 304, 18-63.

22. Niro, S.; Fratianni, A.; Panfili, G.; Falasca, L.; Cinquanta, L.; Alam, M.R. Nutritional evaluation of fresh and dried goji berries cultivated in Italy. Ital. J. Food Sci. 2017, 29. [CrossRef]

23. Dougnon, T.V.; Bankolé, H.S.; Johnson, R.C.; Klotoé, J.R.; Dougnon, G.; Gbaguidi, F.; Rhin, B.H. Phytochemical screening, nutritional and toxicological analyses of leaves and fruits of Solanum macrocarpon Linn (Solanaceae) in Cotonou (Benin). Food Nutr. Sci. 2012, 3, 1595-1603. [CrossRef]

24. Kiełbasa, P.; Juliszewski, T. Pomiar powierzchni liści wybranych roślin metodą video-komputerowa. [Measurement of the leaf surface for the selected plants using video-computer method]. Inżynieria Rol. 2005, 14, 169-175.

25. Antal, T.; Sikolya, L.; Kerekes, B. Assessment of freezing pre-treatments for the freeze dried of apple slices. Acta Univ. Cibiniensis Ser. E Food Technol. 2013, 17, 3-14. [CrossRef]

26. Ochmian, I.; Oszmiański, J.; Lachowicz, S.; Krupa-Małkiewicz, M. Rootstock effect on physico-chemical properties and content of bioactive compounds of four cultivars Cornelian cherry fruits. Sci. Hortic. 2019, 256, 108588. [CrossRef] 
27. Oszmiański, J.; Wojdylo, A. Aronia melanocarpa phenolics and their antioxidant activity. Eur. Food Res. Technol. 2005, 221, 809-813. [CrossRef]

28. Lachowicz, S.; Wiśniewski, R.; Ochmian, I.; Drzymała, K.; Pluta, S. Anti-microbiological, anti-hyperglycemic and anti-obesity potency of natural antioxidants in fruit fractions of saskatoon berry. Antioxidants 2019, 8, 397. [CrossRef]

29. Yusufe, M.; Mohammed, A.; Satheesh, N. Effect of duration and drying temperature on characteristics of dried tomato (Lycopersicon esculentum L.) Cochoro variety. Acta Univ. Cibiniensis Ser. E Food Technol. 2017, 21, 41-50. [CrossRef]

30. Ochmian, I.; Kozos, K.; Mijowska, K. Influence of storage conditions on changes in physical parameters and chemical composition of highbush blueberry (Vaccinium corymbosum L.) fruit during storage. Bulg. J. Agric. Sci. 2015, 21, 178-183.

31. Wojdyło, A.; Nowicka, P.; Babelewski, P. Phenolic and carotenoid profile of new goji cultivars and their anti-hyperglycemic, anti-aging and antioxidant properties. J. Funct. Foods. 2018, 48, 632-642. [CrossRef]

32. Sato, Y.; Itagaki, S.; Kurokawa, T.; Ogura, J.; Kobayashi, M.; Hirano, T.; Sugawara, M.; Iseki, K. In vitro and in vivo antioxidant properties of chlorogenic acid and caffeic acid. Int. J. Pharm. 2011, 403, 136-138. [CrossRef] [PubMed]

33. Wang, C.C.; Chang, S.C.; Inbaraj, B.S.; Chen, B.H. Isolation of carotenoids, flavonoids and polysaccharides from Lycium barbarum L. and evaluation of antioxidant activity. Food Chem. 2010, 120, 184-192. [CrossRef]

34. Pandey, K.B.; Rizvi, S.I. Plant polyphenols as dietary antioxidants in human health and disease. Oxid. Med. Cell. Longev. 2009, 5, 270-278. [CrossRef] [PubMed]

35. Podsedek, A.; Majewska, I.; Redzynia, M.; Sosnowska, D.; Koziołkiewicz, M. In vitro inhibitory effect on digestive enzymes and antioxidant potential of commonly consumed fruits. J. Agric. Food Chem. 2014, 62, 4610-4617. [CrossRef]

36. Montesano, D.; Rocchetti, G.; Cossignani, L.; Lucini, L.; Simonetti, M.S.; Blasia, F. Italian Lycium barbarum L. berry: Chemical characterization and nutraceutical value. Nat. Prod. Commun. 2018, 13, 1934578X1801300913. [CrossRef]

37. Bratu, M.M.; Birghila, S.; Popescu, A.; Negreanu-Pirjol, B.S.; Negreanu-Pirjol, T. Correlation of antioxidant activity of dried berry infusions with the polyphenols and selected microelements contents. Bull. Chem. Soc. Ethiop. 2018, 32, 1-12. [CrossRef]

38. Kumar, D.; Arya, V.; Kaur, R.; Bhat, Z.A.; Gupta, V.K.; Kumar, V. A review of immunomodulators in the Indian traditional health care system. J. Microbiol. Immunol. Infect. 2012, 45, 165-184. [CrossRef]

39. Benzie, I.F.; Devaki, M. The ferric reducing/antioxidant power (FRAP) assay for non-enzymatic antioxidant capacity: Concepts, procedures, limitations and applications. In Measurement of Antioxidant Activity $\mathcal{E}$ Capacity; John Wiley \& Sons Ltd.: Hoboken, NJ, USA, 2017; pp. 77-106.

40. Varadarajan, P.; Rathinaswamy, G.; Asirvatahm, D. Antimicrobial properties and phytochemical constituents of Rheo discolor Hance. Ethnobot. Leafl. 2008, 12, 841-845.

41. Dahech, I.; Farah, W.; Trigui, M.; Hssouna, A.B.; Belghith, H.; Belghith, K.S.; Abdallah, F.B. Antioxidant and antimicrobial activities of Lycium shawii fruits extract. Int. J. Biol. Macromol. 2013, 60, 328-333. [CrossRef]

42. Mijowska, K.; Ochmian, I.; Oszmiański, J. Rootstock effects on polyphenol content in grapes of 'Regent'cultivated under cool climate condition. J. Appl. Bot. Food Qual. 2017, 90, 159-164.

43. Sadowski, A.; Nurzyński, J.; Pacholak, E.; Smolarz, K. Określanie Potrzeb nawożenia Roślin Sadowniczych. II. Zasady, Liczby Graniczne i Dawki Nawożenia. Instrukcja Upowszechnieniowa nr 3; SGGW: Warszawa, Poland, 1990; pp. 1-25.

44. Murashige, T.; Skoog, F. A revised medium for rapid growth and bioassay with tobacco tissue culture. Physiolol. Plant. 1962, 15, 473-497. [CrossRef]

45. Polish Committee for Standardization. PN-R-04016-21. Chemical and Agricultural Analysis of Soil. Determination of the Content of Available Zinc, Copper, Manganese, Iron; Polish Committee for Standardization: Warszav, Poland, 1992.

46. IUNG (Institute of Soil Science and Plant Cultivation). Methods of Laboratory Tests in Chemical Laboratories. Part II. The Study of Plant Material; IUNG: Puławy, Poland, 1972; pp. 25-83.

47. Lityński, T.; Jurkowska, H.; Gorlach, E. Chemical Analysis of Soil; PWN: Warszawa, Poland, 1976; pp. 135-143. 
48. Oszmiański, J.; Lachowicz, S.; Gławdel, E.; Cebulak, T.; Ochmian, I. Determination of photochemical composition and antioxidant capacity of 22 old apple cultivars grown in Poland. Eur. Food Res. Technol. 2018, 244, 647-662. [CrossRef]

49. Dias, M.I.; Barros, L.; Morales, P.; Sánchez-Mata, M.C.; Oliveira, M.B.P.P.; Ferreira, I.C.F. Nutritional parameters of infusions and decoctions obtained from Fragaria vesca L. roots and vegetative parts. LWT Food Sci. Technol. 2015, 62, 32-38. [CrossRef]

50. Benzie, I.F.; Strain, J.J. The ferric reducing ability of plasma (FRAP) as a measure of "antioxidant power": The FRAP assay. Anal. Biochem. 1996, 239, 70-76. [CrossRef]

51. Shimada, K.; Fujikawa, K.; Yahara, K.; Nakamura, T. Antioxidative properties of xanthan on the autoxidation of soybean oil in cyclodextrin emulsion. J. Agric. Food Chem. 1992, 40, 945-948. [CrossRef]

52. Lachowicz, S.; Oszmiański, J.; Rapak, A.; Ochmian, I. Profile and content of phenolic compounds in leaves, flowers, roots, and stalks of Sanguisorba officinalis L. determined with the LC-DAD-ESI-QTOF-MS/MS analysis and their in vitro antioxidant, antidiabetic, antiproliferative potency. Pharmaceuticals 2020, 13, 191. [CrossRef]

53. Nickavar, B.; Yousefian, N. Evaluation of $\alpha$-amylase inhibitory activities of selected antidiabetic medicinal plants. J. Verbr. Lebensm. 2011, 6, 191-195. [CrossRef]

54. Bauer, A.W.; Kirby, W.M.; Sherris, J.C.; Turck, M. Antibiotic susceptibility testing by a standardized single disk method. Am. J. Clin. Pathol. 1966, 45, 493-496. [CrossRef]

55. Inouye, S.; Yamaguchi, H.; Takizawa, T. Screening of the antibacterial effects of a variety of essentials oils on respiratory tract pathogens, using the modified dilution assay method. J. Inf. Chemother. 2001, 7, 251-254. [CrossRef]

56. Ochmian, I.; Kozos, K.; Chelpinski, P.; Szczepanek, M. Comparison of berry quality in highbush blueberry cultivars grown according to conventional and organic methods. Turk. J. Agric. Forest. 2015, 39, 174-181. [CrossRef]

57. Krupa-Małkiewicz, M.; Kosatka, A.; Smolik, B.; Sędzik, M. Induced mutations through EMS treatment and in vitro screening for salt tolerance plant of Petunia $\times$ atkinsiana D. Don. Not. Bot. Horti Agrobot. 2017, 45, 190-196. [CrossRef]

58. Piwowarczyk, R.; Ochmian, I.; Lachowicz, S.; Kapusta, I.; Sotek, Z.; Błaszak, M. Phytochemical parasite-host relations and interactions: A Cistanche armena case study. Sci. Total Environ. 2020, 716, 137071. [CrossRef] [PubMed]

Sample Availability: Samples of the compounds are not available from the authors.

Publisher's Note: MDPI stays neutral with regard to jurisdictional claims in published maps and institutional affiliations.

(C) 2020 by the authors. Licensee MDPI, Basel, Switzerland. This article is an open access article distributed under the terms and conditions of the Creative Commons Attribution (CC BY) license (http://creativecommons.org/licenses/by/4.0/). 